\title{
The relevance of antibiotic supplements in mammalian cell cultures: Towards a paradigm shift
}

\author{
(1) Siti Nazihahasma Hassan, (1) Farizan Ahmad \\ Department of Neurosciences, School of Medical Sciences, Universiti Sains Malaysia; Hospital Universiti Sains Malaysia, \\ Kelantan, Malaysia
}

\section{Date submitted:}

15.03.2020

Date accepted:

20.05.2020

\section{Online publication date:} 15.12.2020

\section{Corresponding Author: Farizan Ahmad PhD, Department of Neurosciences, School of Medical Sciences, Universiti Sains Malaysia; Hospital Universiti Sains Malaysia, Kelantan, Malaysia \\ farizan@usm.my}

ORCID:

orcid.org/0000-0001-6413-7530

Keywords: Antibiotic supplements, cell culture, mammalian cells, undesirable activities, cytotoxic effect, cytostatic effect

\begin{abstract}
Antibiotic supplements remain a key component of mammalian cell culture systems, providing simple and cost-effective preventive measures as well as treatment for bacterial contamination. However, to a certain extent, antibiotic supplements may also have undesirable activities that are not consciously recognized. In fact, customary antibiotic supplements in cell cultures exhibit cytotoxic and cytostatic activity at standard concentrations, as well as altering the biological patterns of cultured mammalian cells. On the other hand, acquired resistance is a matter of great concern that may arise as a result of routine and long-term use of antibiotic supplements. This review addresses the relevance of the use of antibiotic supplements in mammalian cell culture systems, by highlighting their advantages and disadvantages and providing insight into the practices of antibiotic-free culture media.
\end{abstract}

\section{Introduction}

Cell culture is a method by which eukaryotic cells are grown and propagated in vitro with enriched fluid media under controlled conditions. The method was first introduced by Harrison et al. (1), where a small piece of neural tissue isolated from frog embryos placed in a drop of fresh adult frog lymph on a sterile cover slip was observed to grow and form nerve fibers. Since then, the method has been improved and has enabled various cell-based applications through the use of sterile plastic consumables, artificial growth media, and antimicrobial agents such as antibiotics and antifungals $(2,3)$. One of the earliest uses of cell culture was the propagation of poliovirus for vaccine production in the 1950s (4), and in the decades since, the method has been extensively utilized in research and industry, especially in the field of biomedical and pharmaceutical sciences.

Cell culture-based assays are usually performed using primary cells or cell lines-derived from organisms such as humans, rats, and mice. Cells isolated directly from these organisms are called primary cells, while permanently established cells are called cell lines, and these cells are either adherent or suspension. The primary cells have a limited lifespan, but the cell lines are usually indefinite. Presently, mammalian cell culture systems are either two-dimensional (2D), three-dimensional (3D) or co-culture (3). In 2D cultures, cells grow on a flat, rigid surface of standard culture flasks or plates. On the other hand, 3D cultures involve either the use of scaffolds or liquid cultures on low-attachment plates, in hanging 
drops or in rotation, and these methods can be carried out in co-cultures of with different cell types or cellular components.

In in vitro mammalian cell-based studies, bacterial contamination is a major threat and the culture media are usually supplemented with antibiotics as a preventive measure. In particular, the identified contaminated cells will be discarded rather than treated in order to prevent the risk of persistent contamination. However, in some circumstances, including limited cell resources, antibiotic treatment is the ideal way to rescue contaminated cells. Markedly, although antibiotic use has been shown to be an effective method for eliminating bacteria from contaminated cells, it is important to emphasize that their presence in culture media is not inert (Figure 1). The aim of the present review is to discuss the relevance of antibioticsupplemented culture media because mammalian cells are adversely affected by antibiotic supplements, thereby wreaking an error discovery and further fueling concerns about the rise of antibiotic-resistant bacteria over routine and continuous use.

\section{Threats to Mammalian Cell Cultures}

There are three constant threats in mammalian cell culture systems, namely, microbial contamination, cross-contamination, and chemical contamination. These threats can be persistent, hidden, overlooked, and unrecognized (5). In general, all contaminants are hazards to the cell culture system and will affect the reliability and reproducibility of the scientific findings of a particular experiment.

Microbial contamination is most commonly due to the presence of microorganisms such as bacteria and fungi that flourish in cultures (6). These microbes compete for nutrients and cause a shift in the $\mathrm{pH}$ value of the culture media, alter cell metabolism, hinder cell growth, and often lead to cell death. On the other hand, cross-contamination is referred to as the condition of one type of cell contaminated with another type of cell. The widely known cross-contamination is human cervical adenoma cells cross-contaminated with many mammalian cell lines. The gold standard method for authenticating this type of contamination is DNA profiling based on short tandem repeat (7). In addition to microbial and biological sources, contamination may also occur due to chemical residues of disinfectants or detergents in glassware and impurities or toxins in water, media, or other reagents used in cell cultures (8).

It should be noted that microbial contamination is a major and persistent challenge in mammalian cell culture systems, and most cases are due to mycoplasmas $(6,9,10)$. They are the smallest prokaryotes and are difficult to detect either macroscopically or microscopically. Mycoplasma-contaminated cell cultures do not cause the culture media turbidity and $\mathrm{pH}$ changes with no apparent effect on cell growth and cell morphology, and hence remain undetected for many passages $(6,11)$. In point of fact, mycoplasmal contamination alters the biological features of host cells. Sokolova et al. (12) discovered that Mycoplasma bovis sensitized murine T-cell hybridoma 2B4 and several different human cell lines to apoptosis induction. However, Mycoplasma fermentans has been found to cause choline deficiency-induced apoptosis in primary rat astrocytes (13). The impact of Mycoplasma fermentans was also evident

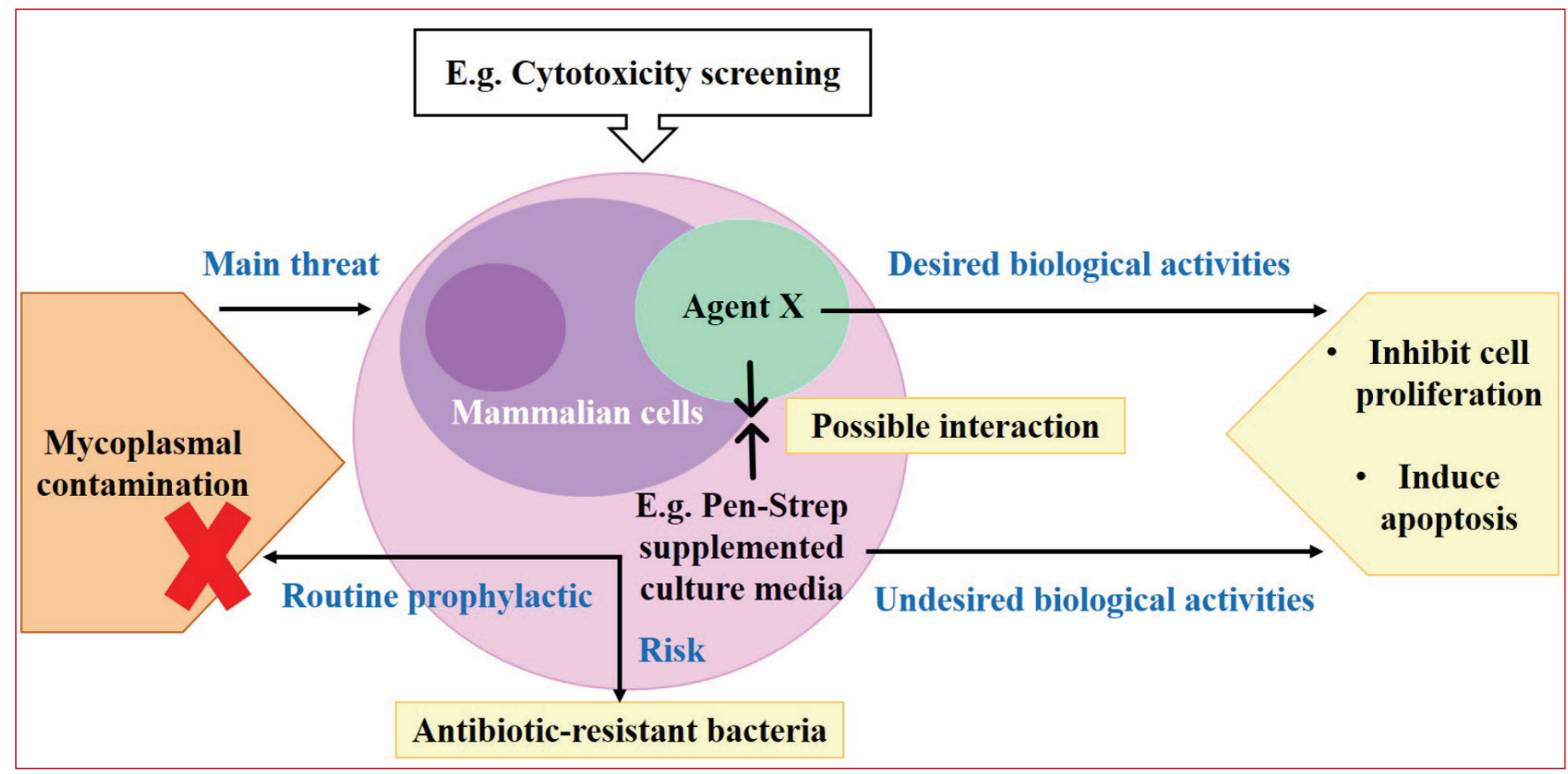

Figure 1. Overview and downside of the customary antibiotic supplements in mammalian cell cultures Pen-Strep: Penicillin-streptomycin, E.g.: For example 
across cytotoxicity as it exerted cytokines-inducing activity in human monocytes and myelomonocytic cell lines (14).

Uphoff and Drexler (9) have shown that the most common mycoplasma species contaminating the cell lines is of human origin, of which about $47 \%$ identified by polymerase chain reaction-restriction fragment length polymorphism method was Mycoplasma fermentans. Other species have been found in mammalian cell lines, including Mycoplasma arginini (bovine), Mycoplasma orale (human), Mycoplasma hyorhinis (swine) and Mycoplasma hominis (human). Mycoplasmas are spread from mycoplasma-contaminated cell lines, cell culturist, animalderived sera, origin of cells, and poor aseptic techniques, as well as cell culture equipment, culture media, and reagents used in the processing mycoplasma-contaminated cell cultures $(6,11,15)$. Another potential source of mycoplasma contamination is the storage of cells in a liquid nitrogen tank in which mycoplasmas are able to survive in liquid nitrogen without cryopreservation and are capable of contaminating cryopreserved cells (16).

\section{Antibiotic Supplements in Mammalian Cell Cultures}

Antibiotics are classified according to their target on bacterial cellular components, which are either bactericidal or bacteriostatic. Bactericidal antibiotics kill bacteria, while bacteriostatic antibiotics inhibit the growth of bacteria. According to Perlman (17), there are seven basic requirements for antibiotic supplements in mammalian cell culture systems; (i) eliminate the microbial contaminants (bactericidal is preferred to bacteriostatic), (ii) do not inhibit growth and metabolism of mammalian cells, (iii) provide protection for the complete experimental period, (iv) do not affect any ultimate use intended for mammalian cells, (v) non-toxic and safe, (vi) compatible with other components in culture media and (vii) inexpensive and not contain excipients. In addition, Schafer et al. (18) suggested that the ideal antibiotic supplements should have broad-spectrum antibacterial and antimycoplasmal activities, but not cause cytotoxicity. It is important to know that antibiotics are stable in the cell culture media for three days at $37^{\circ} \mathrm{C}$ and they are lightsensitive; therefore, stock and working antibiotics as well as cell culture media containing antibiotics must be protected from light $(16,17)$.

At present, one of the most commonly used antibiotic supplements in mammalian cell cultures is a combination of penicillin (Pen) $(100 \mathrm{U} / \mathrm{mL}$ ) and streptomycin (Strep) (100 $\mu \mathrm{g} / \mathrm{mL})(1 \% \mathrm{v} / \mathrm{v})$. Pen is a class of $\beta$-lactam antibiotics that works against Gram-positive bacteria, while Strep is a class of aminoglycoside antibiotic that works against both Gram-positive and Gram-negative bacteria. Both bactericidal antibiotics exhibit synergistic interactions, in which inhibition of bacterial cell wall synthesis by Pen facilitates the entry of Strep into bacteria that impair bacterial protein synthesis. Nevertheless, both antibiotics are sensitive to $\mathrm{pH}$ and temperature changes (18). Pen has a very short half-life at $37^{\circ} \mathrm{C}$ and a rapid loss of activity at acidic and alkaline $\mathrm{pH}$ levels, while Strep has an optimum stability at $28{ }^{\circ} \mathrm{C}$ or below and a progressive loss of activity at alkaline $\mathrm{pH}$ (18-20). On the other hand, Pen activity has been shown to be decreased upon addition to the culture media containing serum and to be completely inactivated following autoclaving (18).

Gentamicin is the second most common antibiotic supplement used in mammalian cell cultures. According to Schafer et al. (18), the biological and biochemical properties of gentamicin are superior than that of Pen and Strep either given alone or in combination. Gentamicin belongs to the aminoglycoside group of antibiotics. It is a protein synthesis inhibitor with bactericidal activity against mycoplasma, Gramnegative, and Gram-positive bacteria. In terms of $\mathrm{pH}$ and temperature stability, gentamicin has been shown to be stable at $37^{\circ} \mathrm{C}$ in both acidic and alkaline $\mathrm{pH}$ for 15 days and has not been affected by the presence of serum. In addition, gentamicin was found to be completely stable following 15 minutes of autoclaving at $121{ }^{\circ} \mathrm{C}$ with $15 \mathrm{lb}$ of pressure (18). Gentamicin with the standard concentration $(50 \mu \mathrm{g} / \mathrm{mL})$ was demonstrated to have no noticeable effect on morphology, growth and metabolism of a number of mammalian cells $(18,21)$. It is usually supplemented in cell culture media either alone or in combination with other antibiotics, mainly Pen-Strep.

Other antibiotics used for prophylaxis in mammalian cell cultures include ampicillin, erythromycin, and kanamycin, but are less popular. The recommended concentration for these antibiotics is $100 \mu \mathrm{g} / \mathrm{mL}(1 \% \mathrm{v} / \mathrm{v})$. Ampicillin ( $\beta$-lactam antibiotic) is a cell wall synthesis inhibitor with bactericidal activity against both Gram-positive and Gram-negative bacteria, while erythromycin (macrolide antibiotic) is a protein synthesis inhibitor with bacteriostatic activity against mycoplasma and Gram-positive bacteria. On the other hand, kanamycin (aminoglycoside antibiotic) is a protein synthesis inhibitor with bactericidal activity against mycoplasma, Gram-positive and Gram-negative bacteria $(17,22,23)$. Additionally, fluoroquinolone (0.5 to $25 \mu \mathrm{g} / \mathrm{mL}$ ), combination of fluoroquinolone/macrolide (25 $\mu \mathrm{g} / \mathrm{mL})$, and pleuromutilin $(10 \mu \mathrm{g} / \mathrm{mL}) /$ tetracycline $(5 \mu \mathrm{g} /$ $\mathrm{mL}$ ) are anti-mycoplasma antibiotics that have been shown to be effective in eliminating mycoplasmas from contaminated cell lines $(10,16)$. Fluoroquinolone is a nucleic acid synthesis inhibitor with bactericidal activity, while both pleuromutilin and tetracycline are protein synthesis inhibitors with bacteriostatic activity. It is important to note that these anti-mycoplasma antibiotics are not recommended for prophylactic purposes or are routinely used in cell cultures.

1. Use and Effect of Antibiotic Supplements in Mammalian Cell Cultures

As far as bacterial contamination is concerned, the antibiotic-supplemented culture media has become a key 
approach. Indeed, antibiotics have caused undesirable side effects in cultured cells differently depending on the cell types. For example, gentamicin exerted a significant cytostatic effect on rabbit keratocytes only at a concentration of $3,000 \mu \mathrm{g} /$ $\mathrm{mL}$ (24). On the other hand, in human osteoblast-like cells, gentamicin engendered a dose-dependent cytostatic effect at concentrations of $100 \mu \mathrm{g} / \mathrm{mL}$ and above (25). Gentamicin, on the other hand, induced cytotoxic effects on human embryonic stem cells (hESCs) during directed differentiation towards hepatic and neural fate at a concentration of $10 \mu \mathrm{g} / \mathrm{mL}$, but did not affect undifferentiated hESCs (26). Induction of apoptotic cell death by gentamicin in different types of renal cell lines and rat embryonic fibroblasts has been shown to be dose- and timedependent (27). Here, the advantages and disadvantages of the use of antibiotic supplements in mammalian cell cultures are summarized as follows.

\subsection{Advantages}

In primary culture, the use of Pen-Strep-supplemented phosphate buffer saline (PBS) to rinse the cells during initial isolation and Pen-Strep-supplemented culture media has been shown to be effective in preventing bacterial contamination (28). Equally important, mycoplasma-contaminated cells can be treated with antibiotic classes such as tetracyclines, macrolides, fluoroquinolones, and pleuromutilins. These anti-mycoplasma regimens have been shown to be effective in eliminating mycoplasma from contaminated cells, 96\% of which were permanently mycoplasma-free (10). In either case, antibiotic supplements may be needed when working with precious cells and limited cell resources, either in culture media or alternatively in PBS for cell washing.

\subsection{Disadvantages}

Despite the efficacy of antibiotics in the elimination and prevention of bacterial contamination in mammalian cell cultures, it has indeed been shown to alter the biological features of cells at cellular and molecular levels (26,29-31). Uphoff et al. (10) reported that around 3 to $11 \%$ of cell culture losses were due to anti-mycoplasma antibiotics-induced cytotoxicity. On the other hand, the universal prophylactic approach, such as Pen-Strep, is generally thought to cause cytotoxic, cytostatic, and other undesirable effects on mammalian cells at higher concentrations than recommended. As a matter of fact, Varghese et al. (26) showed that Pen-Strep (100 U/mL-100 $\mu \mathrm{g} / \mathrm{mL})$ did not affect the viability of undifferentiated hESCs after 2- and 5-day posttreatment, but induced apoptotic cell death without significant reduction in cell viability on day 10 of neural differentiation. Standard 1\% Pen-Strep-supplemented culture medium has also been demonstrated to induce changes in HepG2 human liver cancer cells at molecular level (31). Then again, Bertram (32) found that Pen with a concentration of $100 \mathrm{U} / \mathrm{mL}$ suppressed 3-methylcholanthrene (MCA)-induced malignant transformation of mouse embryo cells (C3H/10T1/2). The inhibitory effect of Pen on MCA-induced malignant transformation in $\mathrm{C} 3 \mathrm{H} / 10 \mathrm{~T} 1 / 2$ cells has also been discovered to be dose-dependent. On the other hand, a study discovered that Pen $(150 \mathrm{U} / \mathrm{mL})$ did not inhibit muscle development in primary culture of chick myoblasts (33). Table 1 summarizes the reported side effects of the antibiotic supplements on mammalian cells identified in this literature review.

Accordingly, the use of antibiotic supplements in mammalian cell cultures requires careful consideration as the drawbacks are greater than the benefits. It is important to point out that antibiotics exhibit concentration-dependent effects and the response of different mammalian cells to different antibiotic supplements may vary. In the light of pharmacodynamic interactions, the presence of antibiotic supplements in culture media could potentially interact with any type of test agent $(32,34)$. The resulting interaction may increase or decrease the effect of a particular agent and ultimately lead to improper scientific results. With this in mind, studies that focus on cytotoxicity or anticancer screening, as well as any mammalian cell-based assay, are better not to use antibiotic-supplemented culture media.

\section{Prophylactic Practice in Mammalian Cell Cultures}

From the mid-19th century to the present, the use of Pen-Strep- or gentamicin-supplemented culture media or a combination of both to prevent bacterial contamination remains widespread. Kuhlmann (23) stated that the use of antibioticsupplemented culture media was unsuitable because antibiotics interfered with cultured cells, yielding incomparable culture conditions and unreliable findings. On the other hand, regular use of antibiotics is not recommended as it may delay detection and mask low levels of bacterial contamination $(5,15)$. Furthermore, the use of antibiotic-supplemented culture media for unnecessarily prolonged periods could contribute to an increase in antibiotic-resistant bacteria, which may result in unmanageable bacterial contamination in mammalian cell culture systems $(10,15)$. One group found that the general prophylactic use of Pen-Strep was insensitive to prevent and eliminate mycoplasmal contamination. Gram-negative, such as Klebsiella species, Providencia species, and Pseudomonas aeruginosa as well as one out of five strains of the Grampositive Staphylococcus aureus have indeed been shown to be resistant to Pen-Strep (21). Additionally, Kastrop et al. (20) discovered that $91.4 \%$ of the bacterial strains were either Penor Strep-resistant or both, and most of which were Escherichia coli.

From now on, the use of prophylactic antibiotics should be limited and discouraged for long-term routine use. Antibiotic supplements certainly do not provide an optimal preventive effect without aseptic techniques and a biological safety cabinet while performing cell culture work. By all means, bacterial- 


\begin{tabular}{|c|c|c|c|}
\hline Antibiotic (s) (Concentration) & Cells/Cell line & Significance & Reference \\
\hline $\begin{array}{l}\text { Fluoroquinolones } \\
(3,30,300 \text { and } 3,000 \mu \mathrm{g} / \mathrm{mL})\end{array}$ & Rabbit keratocytes & Antiproliferative & Seitz et al. (24) \\
\hline $\begin{array}{l}\text { Gentamicin } \\
(100,300 \text { and } 700 \mu \mathrm{g} / \mathrm{mL})\end{array}$ & $\begin{array}{l}\text { Human osteoblast-like } \\
\text { cells }\end{array}$ & Antiproliferative; decrease ALP activity & Isefuku et al. (25) \\
\hline $\begin{array}{l}\text { Gentamicin }(10-200 \mu \mathrm{g} / \mathrm{mL}) \text { with } \\
\text { or without Pen-Strep } \\
(100 \mathrm{U} / \mathrm{mL}-100 \mu \mathrm{g} / \mathrm{mL})\end{array}$ & $\begin{array}{l}\text { hESCs (post hepatic and } \\
\text { neural differentiation) }\end{array}$ & $\begin{array}{l}\text { Antiproliferative; induce apoptosis; decrease } \\
\text { the gene expression of neural stem cell } \\
\text { markers }\end{array}$ & Varghese et al. (26) \\
\hline Gentamicin (2 mM) & $\begin{array}{l}\text { Rat embryonic fibroblasts; } \\
\text { LLC-PK1; MDCK }\end{array}$ & Induce apoptosis & $\begin{array}{l}\text { El Mouedden et al. } \\
\text { (27) }\end{array}$ \\
\hline $\begin{array}{l}\text { Pen-Strep }(50,100 \text { and } 200 \mathrm{U} / \\
\mu \mathrm{g} / \mathrm{mL}) ; \text { gentamicin } \\
(10,25 \text { and } 50 \mu \mathrm{g} / \mathrm{mL})\end{array}$ & hiPSC-CMs & $\begin{array}{l}\text { Induce electrophysiological changes; } \\
\text { decrease the gene expression of sodium } \\
\text { and potassium ion channels }\end{array}$ & Hyun et al. (29) \\
\hline $\begin{array}{l}\text { Ciprofloxacin }(10 \mu \mathrm{g} / \\
\mathrm{mL}) ; \text { ampicillin }(20 \mu \mathrm{g} / \mathrm{mL}) \text {; } \\
\text { kanamycin }(25 \mu \mathrm{g} / \mathrm{mL})\end{array}$ & $\begin{array}{l}\text { MCF10A, PAEC, HMEC, } \\
\text { CACO-2 and NHDF }\end{array}$ & $\begin{array}{l}\text { Induce oxidative stress and mitochondrial } \\
\text { damage }\end{array}$ & Kalghatgi et al. (30) \\
\hline Pen-Strep (1\% v/v) & HepG2 & $\begin{array}{l}\text { Induce global changes in the gene } \\
\text { expression and chromatin landscape }\end{array}$ & Ryu et al. (31) \\
\hline Gentamicin (50 and $100 \mu \mathrm{g} / \mathrm{mL})$ & $\mathrm{C} 3 \mathrm{H} / 10 \mathrm{~T} 1 / 2$ & Antiproliferative & Bertram (32) \\
\hline Strep (50 and $100 \mu \mathrm{g} / \mathrm{mL}$ ) & Chick embryo muscle cells & Delay myogenesis & Moss et al. (33) \\
\hline Gentamicin (0.1 mM) & MDCK-C11 & $\begin{array}{l}\text { Antiproliferative; induce morphological and } \\
\text { ultrastructural changes, and increase in } \\
\text { intracellular calcium level }\end{array}$ & Coutinho et al. (35) \\
\hline Gentamicin (50 and $200 \mu \mathrm{g} / \mathrm{mL}$ ) & hMSCs & Inhibit osteoblastic cell differentiation & Kagiwada et al. (36) \\
\hline $\begin{array}{l}\text { Pen-Strep } \\
(100 \mathrm{U} / \mathrm{mL}-100 \mu \mathrm{g} / \mathrm{mL})\end{array}$ & $\begin{array}{l}\text { Human adipose-derived } \\
\text { MSCs }\end{array}$ & $\begin{array}{l}\text { Antiproliferative; increase the gene } \\
\text { expression of MSCs, adipose tissue, and } \\
\text { osteoblastic markers }\end{array}$ & Skubis et al. (37) \\
\hline $\begin{array}{l}\text { Pen; gentamicin; ciprofloxacin } \\
(100 \mu \mathrm{g} / \mathrm{mL})\end{array}$ & Human osteoblasts & Antiproliferative; decrease ALP activity & Rathbone et al. (38) \\
\hline Gentamicin (10 mM) & LLC-PK1 & Induce apoptosis & Choi et al. (39) \\
\hline $\begin{array}{l}\text { Gentamicin }(100 \mu \mathrm{g} / \mathrm{mL}) \\
\text { Pen-Strep }(100 \mathrm{U} / \mathrm{mL}-100 \mu \mathrm{g} / \mathrm{mL})\end{array}$ & Murine ESCs & $\begin{array}{l}\text { Antiproliferative; reduce cell differentiation } \\
\text { efficiency }\end{array}$ & Cohen et al. (40) \\
\hline $\begin{array}{l}\text { Gentamicin } \\
(100 \text { and } 500 \mu \mathrm{g} / \mathrm{mL})\end{array}$ & $\begin{array}{l}\text { Human embryonic lung } \\
\text { fibroblasts }\end{array}$ & Antiproliferative & Litwin (41) \\
\hline Gentamicin $(1,000 \mu \mathrm{g} / \mathrm{mL})$ & Human keratinocytes & Antiproliferative & Cooper et al. (42) \\
\hline $\begin{array}{l}\text { Pen ( } 5 \mathrm{mM}) \text {; Strep ( } 5 \mathrm{mM}) \text {; } \\
\text { gentamicin ( } 3 \mathrm{mM})\end{array}$ & Rat hepatocytes & $\begin{array}{l}\text { Inhibit protein synthesis and protein } \\
\text { degradation }\end{array}$ & $\begin{array}{l}\text { Schwarze and } \\
\text { Seglen (43) }\end{array}$ \\
\hline $\begin{array}{l}\text { Pen-Strep } \\
(1,000 \mu \mathrm{g} / \mathrm{mL}-33 \mu \mathrm{g} / \mathrm{mL})\end{array}$ & Rat adipocytes & $\begin{array}{l}\text { Induce changes in heparin-releasable } \\
\text { lipoprotein lipase activity }\end{array}$ & $\begin{array}{l}\text { Goldstein and } \\
\text { Johnson (44) }\end{array}$ \\
\hline $\begin{array}{l}\text { Pen }(100-300 \mathrm{U} / \mathrm{mL}) \\
\text { gentamicin }(6.5-50 \mu \mathrm{g} / \mathrm{mL}) \text {; } \\
\text { Strep }(50 \mu \mathrm{g} / \mathrm{mL})\end{array}$ & Mice brain cells & Inhibit sulfatide synthesis & Amonn et al. (45) \\
\hline Gentamicin (1 mM) & LLC-PK1 & $\begin{array}{l}\text { Antiproliferative; decrease intracellular } \\
\text { cyclic adenosine monophosphate } \\
\text { level; increase the number and size of } \\
\text { lysosomes, and the activity of N-acetyl-B-D- } \\
\text { glucosaminidase, aminopeptidase, and ALP }\end{array}$ & Hori et al. (46) \\
\hline
\end{tabular}


free mammalian cell cultures can be achieved without relying on antibiotic supplements, but by following standard aseptic techniques along with a clean and well-maintained cell culture environment and equipment. In any scenario, the potential for bacterial contamination cannot be completely eliminated. Consistent practice of good aseptic techniques and sterilization of all consumables and reagents warrant the use of antibiotic-free culture media. It is important to note that bacterial contamination can occur at any stage of cell cultures and must therefore be visually and routinely assessed for the evidence of contamination.

In addition, it is suggested that the newly purchased mammalian cell line be thawed and maintained in antibioticfree culture media in order to be able to rule out possible contamination due to Gram-negative and Gram-positive bacteria, yeast as well as mould. Then again, due to the high prevalence of mycoplasmal contaminations in mammalian cell lines, it is necessary to authenticate that the cells are free of them. Mycoplasmas, however, are difficult to detect by visual observations and are mostly identified by molecular-based assays $(6,9,12)$. Mycoplasma-contaminated cell cultures are often occult, but are known to cause changes in cellular and molecular signatures of cells (12-14).

\section{Conclusion}

The primary role of antibiotic supplements is to eliminate the bacteria from contaminated mammalian cells. However, for many years, the vast majority of mammalian cell-based studies have been using culture media supplemented with antibiotics on the basis of preventing bacterial contamination. In fact, this paradigm needs to be halted because antibiotics are biologically and pharmacologically active. In addition to the emergence of antibiotic-resistant bacteria, antibiotics could have multilevel effects on eukaryotic cells and may react with any agent or substance in culture media. In this sense, antibiotic-free culture media are recommended to ensure the reliability and reproducibility of mammalian cell culture systems-derived scientific findings.

\section{Ethics}

Peer-review: Externally peer-reviewed.

\section{Authorship Contributions}

Concept: S.N.H., F.A., Design: S.N.H., F.A., Data Collection or Processing: S.N.H., F.A., Analysis or Interpretation: S.N.H., F.A., Literature Search: S.N.H., Writing: S.N.H., F.A.

Conflict of Interest: No conflict of interest was declared by the authors.

\section{Acknowledgements}

We would like to express our gratitude to the Fundamental Research Grant Scheme (FRGS), 203/PPSP/6131203 and the USM Fellowship provided by Universiti Sains Malaysia.

\section{References}

1. Harrison RG, Greenman M, Mall FP, Jackson C. Observations of the living developing nerve fiber. Anat Rec. 1907;1:116-128.

2. Carrel A, Burrows MT. Cultivation of tissues in vitro and its technique. J Exp Med. 1911;13:387.

3. Breslin S, O'Driscoll L. Three-dimensional cell culture: the missing link in drug discovery. Drug Discov Today. 2013;18:240-249.

4. WellerTH, Robbins FC, Enders JF. Cultivation of poliomyelitis virus in cultures of human foreskin and embryonic tissues. Proc Soc Exp Biol Med. 1949;72:153-155.

5. Lincoln CK, Gabridge MG. Cell culture contamination: sources, consequences, prevention, and elimination. Methods Cell Biol. 1998;57:49-65.

6. Mirjalili A, Parmoor E, Bidhendi SM, Sarkari B. Microbial contamination of cell cultures: a 2 years study. Biologicals. 2005;33:81-85.

7. Bian X, Yang Z, Feng H, Sun H, Liu Y. Combination of species identification and STR profiling identifies crosscontaminated cells from 482 human tumor cell lines. Scientific Reports. 2017;7:1-10.

8. Ryan JA. Understanding and managing cell culture contamination. Corning Incorporated. 1994:1-24.

9. Uphoff CC, Drexler HG. Comparative PCR analysis for detection of mycoplasma infections in continuous cell lines. In Vitro Cell Dev Biol Anim. 2002;38:79-85.

10. Uphoff C, Meyer C, Drexler H. Elimination of mycoplasma from leukemia-lymphoma cell lines using antibiotics. Leukemia. 2002;16:284.

11. Rottem S, Barile MF. Beware of mycoplasmas. Trends Biotechnol. 1993;11:143-151.

12. Sokolova IA, Vaughan AT, Khodarev NN. Mycoplasma infection can sensitize host cells to apoptosis through contribution of apoptotic-like endonuclease (s). Immunol Cell Biol. 1998;76:526-534.

13. Ben-Menachem G, Mousa A, Brenner T, Pinto F, Zähringer $U$, Rottem S. Choline deficiency induced by Mycoplasma fermentans enhances apoptosis of rat astrocytes. FEMS Microbiol Lett. 2001;201:157-162.

14. Rawadi G, Roman-Roman S, Castedo M, et al. Effects of Mycoplasma fermentans on the myelomonocytic lineage. Different molecular entities with cytokine-inducing and cytocidal potential. The J Immunol. 1996;156:670-678.

15. Drexler HG, Uphoff CC. Mycoplasma contamination of cell cultures: Incidence, sources, effects, detection, elimination, prevention. Cytotechnology. 2002;39:75-90.

16. Uphoff CC, Drexler HG. Elimination of mycoplasmas from infected cell lines using antibiotics. Cancer Cell Culture: Springer; 2011:105-114.

17. Perlman D. Use of antibiotics in cell culture media. Methods Enzymol. 1979;58:110-116. 
18. Schafer TW, Pascale A, Shimonaski G, Came PE. Evaluation of gentamicin for use in virology and tissue culture. Appl Microbiol. 1972;23:565-570.

19. Regna PP, Wasselle LA, Solomons I. The stability of streptomycin. J Biol Chem. 1946;165:631.

20. Kastrop PM, de Graaf-Miltenburg LA, Gutknecht DR, Weima SM. Microbial contamination of embryo cultures in an ART laboratory: sources and management. Hum Reprod. 2007;22:2243-2248.

21. Fischer AB. Gentamicin as a bactericidal antibiotic in tissue culture. Med Microbiol Immunol. 1975;161:23-39.

22. Ocampo PS, Lázár V, Papp B, et al. Antagonism between Bacteriostatic and Bactericidal antibiotics is prevalent. Antimicrobial Agents Chemother. 2014;58:4573-4582.

23. Kuhlmann I. The prophylactic use of antibiotics in cell culture. Cytotechnology. 1995;19:95-105.

24. Seitz B, Hayashi S, Wee WR, LaBree L, McDonnell PJ. In vitro effects of aminoglycosides and fluoroquinolones on keratocytes. Invest Ophthalmol Vis Sci. 1996;37:656-665.

25. Isefuku S, Joyner CJ, Simpson AHR. Gentamicin may have an adverse effect on osteogenesis. Journal Orthop Trauma. 2003;17:212-216.

26. Varghese DS, Parween S, Ardah MT, et al. Effects of aminoglycoside antibiotics on human embryonic stem cell viability during differentiation in vitro. Stem Cells Int. 2017;2017:2451927.

27. El Mouedden M, Laurent G, Mingeot-Leclercq MP, Tulkens PM. Gentamicin-induced apoptosis in renal cell lines and embryonic rat fibroblasts. Toxicol Sci. 2000;56:229-239.

28. Campos C, Bernuci M, Vireque A, et al. Preventing microbial contamination during long-term in vitro culture of human granulosa-lutein cells: an ultrastructural analysis. ISRN Obstet Gynecol. 2012;2012:152781.

29. Hyun SW, Kim BR, Lin D, Hyun SA, Seong Shoon Yoon SS, Seo JW. The effects of gentamicin and penicillin/ streptomycin on the electrophysiology of human induced pluripotent stem cell-derived cardiomyocytes in manual patch clamp and multi-electrode array system. Journal of Pharmacol Toxicol Methods. 2018;91:1-6.

30. Kalghatgi S, Spina CS, Costello JC, et al. Bactericidal antibiotics induce mitochondrial dysfunction and oxidative damage in mammalian cells. Sci Transl Med. 2013;5:192ra185.

31. Ryu AH, Eckalbar WL, Kreimer A, Yosef N, Ahituv N. Use antibiotics in cell culture with caution: genomewide identification of antibiotic-induced changes in gene expression and regulation. Sci Rep. 2017;7:7533.

32. Bertram JS. Reduction in the formation of carcinogeninduced transformed foci by penicillin $G$ sodium in the C3H/10T1/2 CL8 cell line. Cancer Lett. 1979;7:289-298.
33. Moss PS, Spector DH, Glass CA, Strohman RC. Streptomycin retards the phenotypic maturation of chick myogenic cells. In Vitro. 1984;20:473-478.

34. Kabins SA. Interactions among antibiotics and other drugs. JAMA. 1972;219:206-212.

35. Coutinho A, Biscaia S, Fernandez R, Tararthuch A. The aminoglycoside antibiotic gentamicin is able to alter metabolic activity and morphology of MDCK-C11 cells: a cell model of intercalated cells. Brazilian J Med Biol Res. 2018;51:1-7.

36. Kagiwada H, Fukuchi T, Machida H, Yamashita K, Ohgushi $\mathrm{H}$. Effect of gentamicin on growth and differentiation of human mesenchymal stem cells. J Toxicol Pathol. 2008;21:61-67.

37. Skubis A, Gola J, Sikora B, et al. Impact of antibiotics on the proliferation and differentiation of human adipose-derived mesenchymal stem cells. Int J Mol Sci. 2017;18:2522.

38. Rathbone CR, Cross JD, Brown KV, Murray CK, Wenke JC. Effect of various concentrations of antibiotics on osteogenic cell viability and activity. J Orthop Res. 2011;29:1070-1074.

39. Choi KH, Kim TI, Chong DL, Lee HY, Han DS. Gentamicin induced apoptosis of renal tubular epithelial (LLC-PK1) cells. The Korean J Intern Med. 2000;15:218.

40. Cohen S, Samadikuchaksaraei A, Polak JM, Bishop AE. Antibiotics reduce the growth rate and differentiation of embryonic stem cell cultures. Tissue Eng. 2006;12:20252030.

41. Litwin J. The effect of commercial and pure gentamicin on the growth of human diploid lung fibroblasts. Acta Pathol Microbiol Scand B Microbiol and Immunol. 1970;78:273276.

42. Cooper ML, Boyce ST, Hansbrough JF, Foreman TJ, Frank $\mathrm{DH}$. Cytotoxicity to cultured human keratinocytes of topical antimicrobial agents. J Surg Res. 1990;48:190-195.

43. Schwarze PE, Seglen PO. Effects of antibiotics on protein synthesis and degradation in primary cultures of rat hepatocytes. In Vitro. 1981;17:71-76.

44. Goldstein A, Johnson P. Primary culture of adipoblasts from obese and lean Zucker rat adipose tissue. Metabolism. 1982;31:601-607.

45. Amonn F, Baumann U, Wiesmann UN, Hofmann K, Herschkowitz N. Effects of antibiotics on the growth and differentiation in dissociated brain cell cultures. Neuroscience. 1978;3:465-468.

46. Hori R, Yamamoto K, Saito H, Kohno M, Inui K. Effect of aminoglycoside antibiotics on cellular functions of kidney epithelial cell line (LLC-PK1): a model system for aminoglycoside nephrotoxicity. J Pharmacol Exp Ther. 1984;230:742-748. 